\title{
Puzzling tax attitudes and labels
}

\author{
Åsa Löfgren and Katarina Nordblom* \\ Working Paper in Economics no. 234
}

October 18, 2006

\begin{abstract}
We find that through labeling one can significantly affect attitudes towards a tax. The gasoline tax meets a stronger reluctance than virtually the same tax when it is called the $\mathrm{CO}_{2}$ tax on gasoline.
\end{abstract}

JEL classification: H23; Q58.

Keywords: Gasoline tax; $\mathrm{CO}_{2}$ tax on gasoline; attitude; framing.

${ }^{*}$ Department of Economics, Göteborg University, Box 640, SE-405 30 Göteborg, Sweden. E-mail: asa.lofgren@economics.gu.se or katarina.nordblom@economics.gu.se. This research was financially supported by CLIPORE and the Malmsten Foundation. 


\section{Introduction}

Hammar et al. (2006) find that the $\mathrm{CO}_{2}$ tax on gasoline and diesel is one of the most accepted Swedish taxes. This finding is contradicted in the public Swedish debate, where the gasoline tax is proclaimed as one of the most unpopular taxes. ${ }^{1}$ This discrepancy is indeed puzzling - is the tax one of the most, or one of the least popular taxes in Sweden?

One likely explanation lies in the labeling of the tax (note the different names for the tax in the above mentioned studies, i.e. the gasoline tax vs. the $\mathrm{CO}_{2}$ tax on gasoline). The different labels can been seen as a matter of framing. That people can be affected by the framing of choices is well known (see e.g. Tversky and Kahneman, 1981, 1986). McCaffery and Baron (2004) find that the so called attribute framing "...emphasizing a positive or negative aspect of an item under consideration" (p. 681.) could be important in relation to tax policies. The $\mathrm{CO}_{2}$ tax label could give a positive association due to the effect of $\mathrm{CO}_{2}$ on climate change, while the label gasoline tax could be viewed as negative, and mostly associated with a high price of fuel. Is it as simple as that - that the words we use to describe a tax determine people's opinions about it?

In order to find this out, we have conducted a survey in a very homogenous group, namely economics students at Göteborg University in Sweden. Half of the sample were asked about their opinion about the $\mathrm{CO}_{2}$ tax on gasoline and half of the sample about the gasoline tax. Economics students are less likely (we think) to be deceived by the different tax labels and should be better informed than a representative citizen about the properties of different taxes. Therefore it was surprising to see the large difference in answers between the two groups. $56 \%$ of those who got the question about the gasoline tax wanted a reduction, while the corresponding figure for the $\mathrm{CO}_{2}$ tax on gasoline was only $29 \%$.

We can therefore conclude that framing is indeed important. Gasoline tax has an unpleasant ring, which makes the attitudes towards it more negative. Reductions of $\mathrm{CO}_{2}$ emissions have been widely discussed in the light of climate change and many people think that this is an urgent task, implying that the tax gains more support with the $\mathrm{CO}_{2}$ label on it.

\section{Data and Results}

The Swedish excise tax on gasoline consists of two parts, the $\mathrm{CO}_{2}$ tax and an energy tax. The $\mathrm{CO}_{2}$ tax is SEK 2.13 per liter gasoline and the total excise tax is SEK 5 per liter (2006). ${ }^{2}$ This means that the questions about the gasoline tax

\footnotetext{
${ }^{1}$ We don't have any representative studies, but according to SIFO, $68 \%$ of people in Stockholm want a reduced gasoline tax (the survey was conducted in May and June 2006). In September 2006, Motormännen had collected 1.3 million names in favor of a reduced gasoline tax, one of the largest protest in its kind ever.

${ }^{2}$ The gasoline taxation in Sweden has over time been fairly average compared to other OECD countries.
} 
and the $\mathrm{CO}_{2}$ tax are not identical, but it is not likely that people want a higher $\mathrm{CO}_{2}$ tax, while they support a reduced over all gasoline tax, or vice versa.

Our sample consists of 119 economics students at Göteborg University. Although small, the sample should be sufficient for testing the labeling effect on attitudes, since the respondents belong to a homogeneous group concerning age and educational attainment. 50 students were asked about their opinion about the gasoline tax and 69 about their opinion about the $\mathrm{CO}_{2}$ tax on gasoline. The question was: Do you think the tax should be increased or decreased? The answers to the question are presented in Table $1 .^{3}$

Table 1: Tax attitudes, in percent.

\begin{tabular}{l|cccccccc} 
& Abolish & $\begin{array}{c}\text { Decrease } \\
\text { a lot }\end{array}$ & $\begin{array}{c}\text { Decrease } \\
\text { a little }\end{array}$ & $\begin{array}{c}\text { Keep it } \\
\text { unchanged }\end{array}$ & $\begin{array}{c}\text { Increase } \\
\text { a little }\end{array}$ & $\begin{array}{c}\text { Increase } \\
\text { a lot }\end{array}$ & $\begin{array}{c}\text { No } \\
\text { opinion }\end{array}$ & $\begin{array}{c}\text { No. } \\
\text { of obs. }\end{array}$ \\
\hline Gasoline tax & 4 & 14 & 38 & 18 & 16 & 4 & 6 & 50 \\
$\mathrm{CO}_{2}$ tax on gasoline & 4 & 9 & 16 & 12 & 23 & 10 & 26 & 69 \\
\hline
\end{tabular}

The respondents who were asked about the gasoline tax were more negative to the tax than those asked about the $\mathrm{CO}_{2}$ tax on gasoline. There were also more respondents who lacked opinion about the $\mathrm{CO}_{2}$ tax on gasoline than on the gasoline tax, although they are approximately the same tax. By using a t-test we find that the mean for the $\mathrm{CO}_{2}$ tax is significantly higher than for the gasoline tax when we exclude those without an opinion. ${ }^{4}$ This highlights the labeling effect that the respondents are more reluctant to the tax when it is referred to as gasoline tax.

Furthermore, we asked about the perception of the tax level and again found significant differences. The open question posed was: How high do you think that the tax is? No-one picked exactly the correct figure, but if we allow a correct answer to deviate with $10 \%$ in each direction, we get answers distributed as in Table 2:

Table 2: Tax perception, in percent.

\begin{tabular}{|c|c|c|c|c|}
\hline & Too low & Correct* & Too high & No opinion \\
\hline Gasoline tax & 22 & 14 & 48 & 16 \\
\hline $\mathrm{CO}_{2}$ tax on gasoline & 33 & 8 & 23 & 36 \\
\hline
\end{tabular}

Gemmell et al. (2004) found that people generally overestimate taxes. On

\footnotetext{
${ }^{3}$ Note that the sample is not representative for the Swedish population, so the results should be interpreted accordingly.

${ }^{4}$ The mean for the gasoline tax is 3.4 where Abolish is assigned 1 and Increase a lot 6 . For the $\mathrm{CO}_{2}$ tax, the mean is 4.0 .
} 
the contrary, in Sausgruber and Tyran (2005) indirect taxes are found to be underestimated. As presented in Table 2, we find that the gasoline tax is overestimated, while the opposite i true for the $\mathrm{CO}_{2}$ tax. However, Sausgruber and Tyran (2005) also find that framing is important for misperception, which we indeed also can conclude.

Next, we run a probit to study determinants for individuals' willingness to decrease the tax. The dependent variable is a dummy variable referring to if the individual wants to decrease or abolish the tax $(=1)$ or not $(=0)$. In a first step, we pool the two samples, and include a dummy indicating if the questionnaire considered the gasoline tax $(=1)$ or the $\mathrm{CO}_{2}$ tax on gasoline $(=0)$. To see if individuals overestimating the tax are more likely to want a tax cut a dummy variable is included ( $1=$ overestimating), i.e. for any individual's preferred tax level, the stated change should be affected by the perceived current level. Further, we control for gender, where the respondent has grown up, and for car ownership. ${ }^{5}$

The results are presented in Table 3, column one. Overestimation of the tax level increases the probability of wanting a lower tax, which is expected. Notably, the probability that a respondent wants a reduced tax is $23 \%$ higher if the question is stated in terms of the gasoline tax rather than the $\mathrm{CO}_{2}$ tax on gasoline. There is thus a significant difference between the labels. Furthermore, men want to cut the tax to a larger extent than women. Also, to have a car and having grown up in the countryside imply a greater probability of wanting to reduce the tax. In order to find out if these explanatory variables have different effects in the two settings the next step is to run separate regressions for each tax label.

Table 3: Probits for wanting to decrease the tax, marginal effects

\begin{tabular}{l|ccc} 
& Total & Gasoline tax & $\mathrm{CO}_{2}$ tax on gasoline \\
\hline Constant & $-2.22^{* *}$ & -1.28 & $-2.17^{* *}$ \\
Overestimates the tax & $0.26^{* *}$ & 0.01 & $0.48^{* *}$ \\
Gasoline tax & $0.23^{*}$ & & \\
& & & \\
Man & $0.31^{* *}$ & $0.39^{*}$ & 0.14 \\
Countryside & $0.36^{*}$ & $0.41^{*}$ & 0.21 \\
Big city & 0.01 & 0.01 & 0.01 \\
Owns a car & $0.41^{* *}$ & $0.42^{* *}$ & $0.31^{*}$ \\
\hline Number of observations & 119 & 50 & 69 \\
Log likelihood & -57.7 & -27.1 & -26.6 \\
Correct predictions & $75 \%$ & $70 \%$ & $87 \%$ \\
\hline * Significant at 5\%; ${ }^{* *}$ Significant at $1 \%$. &
\end{tabular}

When we run separate regressions with the same explanatory variables, some interesting results emerge. The results are presented in columns two and three in Table 3. Comparing them, it is obvious that there are different explanations

\footnotetext{
${ }^{5}$ Summary statistics for the explanatory variables are presented in Appendix A.
} 
for wanting a tax cut depending on the tax label. First of all, comparing the constants give at hand that the attitude towards a tax cut of the $\mathrm{CO}_{2} \operatorname{tax}$ is undesirable for the reference respondent, which is not the case for the gasoline tax. Further, those who overestimate the $\mathrm{CO}_{2}$ tax are more likely to think that the tax is too high. Unexpectedly, overestimation has no impact on the willingness to reduce the gasoline tax. We interpret this as a more general negative attitude to this tax label, where those who want to cut the gasoline tax are unaffected by the perceived tax level. Also the control variables have different effects in the two regressions. Men are more likely to support a reduced gasoline tax, but there is no gender difference for the $\mathrm{CO}_{2}$ tax on gasoline. People grown up in the countryside want a lower gasoline tax to a larger extent than others, while it has no effect on the willingness to decrease the $\mathrm{CO}_{2}$ tax. In the countryside, people are in more need of cars and therefore potentially more reluctant to high fuel costs. The $\mathrm{CO}_{2}$ tax label does not give this association, and therefore not an extra objection towards the tax. If an individual owns a car, this increases the probability of wanting to decrease the tax, irrespective of tax label. This similarity could reflect that car owners are directly affected, and therefore more aware of this tax than others, so that they are not influenced by the label.

\section{Discussion}

A group of students were asked about their opinion about a tax, which has been highly debated in Sweden. Half of them received the question in terms of the $\mathrm{CO}_{2}$ tax on gasoline, while the rest were asked simply about the gasoline tax. Respondents were much more reluctant to the latter than to the former notion and we even found different explanations of the attitudes towards the two tax labels. From this rather simple exercise, we can conclude that people's opinions about a tax significantly depend on the label put on it.

Our results are consistent with the terminology used in the public debate. The notion gasoline tax has been used by those who oppose the tax, while its advocates talk about the $\mathrm{CO}_{2}$ tax on gasoline. We can speculate about the reasons. Many people associate the gasoline tax with the very high price on gasoline and therefore, it triggers a negative attitude. Calling it $\mathrm{CO}_{2}$ tax on gasoline emphasizes that it is an environmental tax, to which people are less reluctant.

Referring back to our initial dilemma if the tax in question is one of the most or one of the least popular taxes in Sweden, we conclude that the simple answer lies in the label of the tax - you get the answer you ask for. 


\section{References}

Gemmell, N., Morrissey, O., and Pinar, A. (2004). Tax perceptions and preferences over tax structure in the United Kingdom. The Economic Journal, 114:117-138.

Hammar, H., Jagers, S. C., and Nordblom, K. (2006). What explains attitudes towards tax levels? A multi-tax comparison. Working Paper 225, Göteborg University.

McCaffery, E. J. and Baron, J. (2004). Framing and taxation: Evaluation of tax policies involving household composition. Journal of Economic Psychology, 25:679-705.

Sausgruber, R. and Tyran, J.-R. (2005). Testing the Mill hypothesis of fiscal illusion. Public Choice, 122:39-68.

Tversky, A. and Kahneman, D. (1981). The framing of decisions and the psychology of choice. Science, 211:453-458.

Tversky, A. and Kahneman, D. (1986). Rational choice and the framing of decisions. The Journal of Business, 59:251-278.

\section{A Appendix: Summary statistics}

Summary statistics for the explanatory variables are presented in Table A.1. The variable Countryside takes the value 1 if a respondent has grown up in the countryside and Big City = 1 if grown up in Stockholm, Göteborg, or Malmö. The left out category consists of the $27 \%$ who have grown up in a medium-sized town.

Table A.1: Summary statistics

\begin{tabular}{l|c} 
& Mean \\
\hline Man & 0.57 \\
Countryside & 0.16 \\
Big City & 0.55 \\
Owns a car & 0.53 \\
\hline No. of obs. & 119
\end{tabular}

Table A.1 presents the total sample, but the mean values of the two subsamples are not significantly different from each other. 